Policy Research Working Paper 1907

Development Expenditures and the Local Financing Constraint

Albert D. K. Agbonyitor
The inadequacy of local funds is a major financing problem in most low-income economies. It is undercutting the absorption of aid and the sustainability of deveiopment projects.

The World Bank

Eastern Africa Department

Macroeconomics Division II

April 1998 
Policy Research Working Paper 1907

\section{Summary findings}

Focusing on the local financing constraint sheds new light on issues of aid, fiscal reform, and the management of public spending.

The fungibility of aid need not translate into resource flows to fill the local financing gap. Indeed, project aid can widen the local financing gap. To augment direct local financing of development, aid must be nonproject aid that can generate local currency. In the longer term, project aid's effect on local financing lies in its impact on growth and on expanding the base for tax revenues, seigniorage, and borrowing.

When inadequate local financing limits project implementation and effective use of aid, local currency funds are more valuable than project aid, at the margin - and it becomes important to reallocate local funds, to leverage project aid, and to raise the quality of investment projects.

A persistent gap in local financing complicates programs of fiscal reform. For such programs to be effective, the local financing gap has to be confronted directly by matching planned local fund expenditures against expected local fund receipts. This requires a transparent database to develop indicators and to monitor the allocation and use of local resources.

This paper - a product of the Macroeconomics Division II, Eastern Africa Department - is part of a larger effort in the department to understand the effectiveness of development expenditures. Copies of the paper are available free from the World Bank, 1818 H Street NW, Washington, DC 20433. Please contact Lorraine James, room J10-282, telephone 202473-5621, fax 202-473-8262, Internet address ljames@worldbank.org. April 1998. (18 pages)

The Policy Research Working Paper Series disseminates the findings of work in progress to encourage the exchange of ideas about development issues. An objective of the series is to get the findings out quickly, even if the presentations are less than fully polished. The papers carry the names of the authors and should be cited accordingly. The findings, interpretations, and conclusions expressed in this paper are entirely those of the authors. They do not necessarily represent the view of the Worid Bank, its Executive Directors, or the countries they represent. 


\title{
DEVELOPMENT EXPENDITURES AND THE LOCAL FINANCING CONSTRAINT
}

\author{
Albert D. K. Agbonyitor
}

\section{Eastern Africa}

Macroeconomics: AFTM2 



\title{
Development Expenditures and The Local Financing Constraint ${ }^{1}$
}

\begin{abstract}
Inadequacy of local financing has been a major development financing problem in most low income economies, and is cited as a major factor undercutting aid absorption and "sustainability" of development projects. When inadequate local financing limits project implementation and effective aid absorption, it means that local currency funds are more valuable than project aid at the margin. Allocating local funds to leverage project aid resources becomes critical for aid productivity. Project screening and reviews of development expenditure programs need to pay as much attention to assessing the quality of projects financed fully by local funds, as those which are aided. Resource shifts from fully locally-funded projects that enhance the overall quality of public investments should be emphasized.

A fiscal adjustment program focused on matching aggregate resources against aggregate expenditures, while glossing inner local financing imbalances, stands to undercut the execution of the development expenditure program and to frustrate observance of other fiscal and financial benchmarks. A feasible program has to face the local gap directly by matching planned local fund spending against expected local fund receipts, and ensuring that planned development expenditures have adequate matching funds. Improving the local financing data base will help to develop indicators to monitor budgeting for and using local funds efficiently. Since economic growth provides scope to mobilize local funds by expanding the base for tax revenues, seigniorage and domestic borrowing, fiscal reforms need to protect high quality expenditure programs that expand the base for growth.
\end{abstract}

\section{The Importance of Local Funds}

1. For most low income economies, while external aid is instrumental for having access to capital for investment and growth, local funds are indispensable for facilitating the absorption of the aid and for ensuring that it is utilized productively. Yet, the inadequacy of local financing has been a major development financing problem over the past decades. ${ }^{2}$ Inadequate local financing has been an important factor, though not the only one, undercutting the "sustainability" of development projects; weaknesses in local financing were cited in over 60 percent of Bank projects identified as unsustainable in 1994 (World Bank, 1994a, 1995). A typical symptom of the local financing problem is the under-financing of recurrent costs. This is manifested in an inability to pay and retain skilled personnel; failure to maintain basic social and economic infrastructure; disrepair of equipment; and shortage of supplies to deliver services from projects, such as schools, health facilities, and agricultural extension schemes (Peter Heller, 1974; Uma Lele, 1975). Another symptom of the local fund problem is a lack of matching funds even for high quality aided projects. This limits aid absorption and capital formation, and it

\footnotetext{
${ }^{1}$ Helpful comments and suggestions were received from Peter Miovic and Giovanna Prennushi on an earlier draft of this paper. The views expressed are the responsibility of the author.

2

The local funds for budget finance comprise tax revenues; domestic borrowing from the bank and nonbank public; money printing; use of reserves; and various types of non-project aid, such as commodity aid, program loans and cash grants, that generate local currency counterpart funds.
} 
contributes to delayed execution of projects. Various degrees of matching fund problems were experienced in 40 different LDCs in 1991 (World Bank, 1992). Local financing shortages also undermine steady macroeconomic management as governments find it difficult to restrain expenditures in line with prudent fiscal and financial policies. In addition, growing pressure on aid resources has added to concerns in the development community about the need for the low income economies to mobilize greater local financing support and, thereby, assume greater ownership for their development.

2. This paper approaches the local financing constraint problem from a macro-fiscal perspective: What is the nature of the local financing problem? What are its main underlying factors? Does aid necessarily relieve the local financing gap? What are the implications, if any, of the local financing gap for fiscal adjustment? The paper explores answers to these questions. The next section reviews briefly the recent literature on local financing. Section III formulates a simple three-gap model that links local financing with development expenditure management. Section IV examines aid fungibility relative to local funds. Section V discusses local financing and economic growth. Section VI presents country illustrations; the last section presents conclusions.

\section{Historical Overview}

3. The local financing problem is closely linked with the role of government in economic development. Much of the main stream economic development literature and the vision of modernization in most of the developing world from the 1950 s to the 1970 s assigned a major role to the state in promoting economic development. Tony Killick (1978) illustrated this contention convincingly with his analysis of development policy and its implementation in Ghana. The pressures on government to promote growth arose from the expectation of quick improvement in living conditions imparted by independence movements; the "demonstration effect" of high living standards in the industrialized countries; and the political acceptance of a role for the state in providing basic social and economic services (Martin and Lewis, 1956; Musgrave, 1969). As government activities expanded, recurrent cost under-financing and local financing constraint problems gained prominence in the 1970 s and 1980 s from the works of Peter Heller (1974, 1975, 1979), Mead Over (1981), Club du Sahel (1980), and A. Jennings (1983). Heller attributed recurrent cost under-financing to: long gestation period of investments and low growth response to government stimulation; low tax effort; and a bias in aid giving for new capital formation. Mead Over added that surprises, such as unexpected decline in revenues, increases in input costs, changes in government priorities and shifts in input supply conditions, worsened the recurrent cost problem. These factors were compounded by shortcomings in project design, manifested in failure to mobilize beneficiaries and organize efficient cost recovery systems (Uma Lele, 1975, 1979).

4. While lessons from development experience and changes in the world system in recent decades have led to new policies stressing minimal government intrusion in the economy, government remains an important partner in development, nevertheless (J. Stiglitz, 1997). In addition, while aid agencies now provide assistance, which augments local funds, local financing problems persist. This will remain so for some time, in view 
of the generally accepted, even if minimal, role for government in promoting economic development by investing in the activities which the private sector would not otherwise undertake. Such activities tend to use labor and local funds intensively: rural infrastructure; rural health service; environmental quality; education and diffusion of technological knowledge; and an effective system of public administration.

\section{Development Spending and Local Funds}

5. This section builds on the conventional national income accounts framework to formulate a three-gap model for examining the nature of the local financing gap. Eq1 expresses a familiar identity: (G-T) is the fiscal deficit; $G$ is government expenditure; $T$ is revenue; $\mathrm{Sp}$ and $\mathrm{Ip}$ represent private savings and private investments respectively; (M-E) is the current account balance; $M$ represents imports, and $E$ is exports.

$$
(\mathrm{G}-\mathrm{T})=(\mathrm{Sp}-\mathrm{Ip})+(\mathrm{M}-\mathrm{E})
$$

6. Eq1 provides a basis for the "two-gap" thesis; it envisages the economy as constrained by a savings-investment gap and a foreign financing gap (Chennery and Strout, 1966). Given a growth target, if internal savings were to constrain investments, or if the trade gap were to limit imports required for production, foreign aid will, in each case, bridge the financing gap and help to accelerate economic growth. While the proponents of the two-gap model were aware of other constraints on economic growth, the model was focused on the foreign financing gap, and was applied in quantifying the foreign resource requirements for achieving planned growth targets in the LDCs.

7. Various critics have queried the two-gap thesis. J. C. Fei and G. Ranis (1968), and H. Bruton (1969) questioned its theoretical basis and empirical relevance. They queried the conceptual distinction between the two gaps as well as the meaning of the aid requirements for growth that the model generated. They contended that aid, without policy reforms, could perpetuate the financing gaps and impede growth. More recently, C. Burnside and D. Dollar (1997) also raised doubt about the effectiveness of aid; they argue that good policies - particularly good fiscal, monetary and trade policies - are critical to have the desired impact of aid on economic growth. Willaim Easterly (1997) traced the evolution of the financing gap idea: from Harrod-Domar's concept of the incremental capital output ratio (ICOR), to Rostow's stages of growth, to Chennery and Strout, and to others. Easterly raised doubts about the empirical validity of the ICOR concept that underlies the two-gap thesis. In addition, according to Lance Taylor (1993), the two-gap model does not convey the nature of the development financing problems of the LDCs. He proposed that at least a third gap, the fiscal gap, should be added to the two-gap model to account for the "linked fiscal and foreign transfer limitations" on policy reform and development financing plaguing the LDCs today.

8. The advocates as well as critics of the two-gap thesis glossed over the importance of the local resource gap, though they were aware of the problem. Chennery and Strout, for example, discussed the limits to aid absorption and aid productivity posed by factors, such as education and skills, an efficient public administration, and an effective 
institutional organization. They were cognizant that redressing these constraints required sustained internal resource support; however, in application, the two-gap model glossed over the importance of local funds for the execution of projects and for the overall sound economic management that is critical for growth. Similarly, while Taylor was fully cognizant of the import of the fiscal gap, presumption of aid fungibility may have led him to overlook the inner local financing gap that is embedded in the current fiscal gap. (This issue of aid fungibility will be examined later in section IV).

9. The rest of this section formulates a three-gap model for exploring local financing issues. Eq2 is derived from $\mathrm{Eq} 1$ by defining $\mathrm{G}$ as the sum of development expenditure (Gd) and recurrent expenditure (Gr). In Eq2, development expenditure is presented as a counterpart of three financing gaps: (a) the current fiscal gap; (b) the savings-investment gap; and (c) the current account deficit. Since completed development projects have to be maintained and operated, recurrent cost expenditure, Gr, reflects the past levels of Gd. Given revenues and other things the same, increasing Gd will eventually cause the current fiscal deficit, ( $T-G r)$, to widen. Eq3 shows the financing sources of Gd: the current fiscal balance (T-Gr); money printing (MP); use of reserves (UR); domestic borrowing (Bd); local counterpart currency obtained from non-project aid (An); and project aid (FF). Eq4 simplifies Eq3 as the sum of local funds (LF) and foreign funds (FF). In Eq4, LF has domestic resource components and an aid component, An. FF is project aid.

$$
\begin{array}{rlr}
\mathrm{Gd} & =(\mathrm{T}-\mathrm{Gr})+(\mathrm{Sp}-\mathrm{Ip})+(\mathrm{M}-\mathrm{E}) & \mathrm{Eq2} \\
\mathrm{Gd} & =[(\mathrm{T}-\mathrm{Gr})+\mathrm{MP}+\mathrm{UR}+\mathrm{Bd}+\mathrm{An}]+\mathrm{FF} & \mathrm{Eq3} \\
\mathrm{Gd} & =\mathrm{LF}+\mathrm{FF} & \mathrm{Eq4}
\end{array}
$$

10. From Eq2, both private and public sector investments are necessary to foster economic growth. For example, education infrastructure helps to create skills needed to complement private investment activities. From Eq2, (T-Gr) $>0$ provides a recurrent surplus to finance development by providing matching funds for aided projects and supporting fully government-funded projects. The implementation of aided projects as well as fully government funded projects will be difficult if the current surplus is less than the local matching funds required by the projects. (T-Gr) $<0$ means an inability to cover recurrent costs from internal revenues, let alone support project implementation.

11 In the short term, there is no direct causality between the current fiscal gap and investment in development projects. Increased financing for development activity can result from increased private savings as well as lower private investments; from various sources of local funds, including seigniorage, as indicated in Eq3; and from "turnkey" projects, which are executed directly by donors without local matching funds. While high social aspirations often make development expenditure plans exceed expected resources ex ante, an ex post accounting balance is always obtained between the demand for local funds and supply. Most often, this balance is obtained at the cost of reduced quality and quantity of government services, or more indebtedness. The need for fiscal stability and a prudent debt service burden limit dependence on the various local financing sources. 
12. There is an important distinction between the two-gap and three-gap models, with respect to the role of aid. In the two-gap thesis, foreign financing would relax the savings-investment constraint or the trade constraint on growth. In the three-gap thesis with a local financing constraint, aid will not necessarily bridge the current fiscal gap or local financing gap; in fact, project aid may widen the local financing gap. The issue here is not merely the critique that aid without policy reform and adjustment may result in a chronic savings-investment gap and external deficit, or that without economic policy reform aid will not be effective in promoting economic growth (Bruton, 1969; Burnside and Craig, 1997). The point is that project aid can widen the local gap by adding to the matching funds needed to execute the project as well as to the recurrent cost financing required to operate it on completion. For aid to fill the local gap directly, it has to be in the form of a non-project aid that generates local currency counterpart funds. In the longer term, aid would relax the local financing constraint provided it promotes growth and expands the base for mobilizing revenues; for this aid productivity is critical.

13. To illustrate some implications of the local financing constraint, let Gdc in Eq5 represent the resource allocation function for development activity. Assume matching fund requirements, such that on average " $b$ " units of local funds are required to leverage "a" units of project aid. Thus, development activity is constrained by the lesser of LF and $\mathrm{FF}$. (In a complex framework, "a" and "b" would represent vectors of aid leverage coefficients for the sectors, such as health, education, agriculture, and road transport).

$$
\text { Gdc }=F\{\text { Minimum (bLF, aFF) }\}
$$

Eq5

14 From Eq5, let LFu be the binding financing constraint (that is, aFF $>b L F$ ), and let FFu be the complement of LFu. Then the amount of FF that is actually used would be $(\mathrm{b} / \mathrm{a}) \mathrm{LFu}$, where $(\mathrm{b} / \mathrm{a})$ is the matching fund ratio or aid leverage ratio. Therefore, project aid equivalent to ((FF-(b/a)LFu) will not be absorbed. The extra LF required to absorb the unutilized project aid is $((\mathrm{FF}-(\mathrm{b} / \mathrm{a}) \mathrm{LFu})) 1 / \mathrm{b}$. To illustrate with a stylized numerical example in millions of dollars, let $\mathrm{Gr}=800, \mathrm{~T}=780, \mathrm{MP}=31, \mathrm{An}=10$, and $\mathrm{FF}=500$; a $=1$, and $\mathrm{b}=10$. For simplicity, net domestic borrowing and use of reserves are presumed to be zero. LFu is 21 (from T+MP+An-Gr); this is lower than the 50 required to absorb all FF. Since b/a is 10 , the FFu that corresponds to LFu is 210 ; project aid of 290 will be unused. The additional LF needed to absorb all project aid is 29 , that is, US\$ 29 million.

15. It is important to point out that reducing the matching fund requirement or eliminating it will not redress the local financing problem in a sustained manner. Such an action will expand projects funded fully from aid and raise aid dependence. The resulting faster pace of investments will build more pressure for recurrent cost financing for maintenance and operating costs. This means (in terms of Eq2 and Eq3) that $\mathrm{Gr}$ will rise; the current fiscal gap will widen, and the local financing balance will worsen, undermining utilization of investments as well as growth (Deverajan, et al, 1996).

16. The fiscal authorities may respond to the local financing imbalance in various ways. They may limit project implementation so that not all FF will be utilized, or they 
may utilize all FF by employing sources of local funds that pose risks to macroeconomic stability. To illustrate, assume that expanded seigniorage is used to obtain additional local funds. Take an economy with a GDP of about US\$ 7 billion (e.g., Ghana). Let the growth rate be 4.5 percent; the average currency to GDP ratio is 6.5 percent; income elasticity of money demand is 1.5 . Then the seigniorage rate of 0.44 percent of GDP will provide local currency equivalent of US\$ 31 million, a growth in currency of 7 percent. $^{3}$ Generating the additional matching funds of US\$ 29 million to absorb the remaining unused project aid discussed earlier would mean an extra seigniorage of 0.41 percent of GDP, an additional currency growth of 6.5 percent. Typically in an LDC, where the market for treasury bills outside the banking sector is limited, the seigniorage will take the form of treasury bills being held by the central bank, which is the lender of last resort to the government. If the initial seigniorage rate was consistent with stable macroeconomic policies, then the higher seigniorage that absorbs all project aid will risk macroeconomic stability. In addition, expanded seigniorage, with inflation, will have adverse impact on tax revenue and overall local fund mobilization (Easterly, et al, 1995).

17. The main point to be emphasized is that a budgeting process, which focuses on matching aggregate expenditure plans against aggregate resources and glosses over the inner local financing constraint will risk the implementation of development expenditures as well as adherence to a stable macro-fiscal stance. A mismatch between local fund availability and demand will make it difficult to implement the development budget and also observe prudent fiscal and financial targets. To minimize this, the fiscal authorities must assess the local fund balance explicitly by matching planned local fund expenditures against local fund receipts to ensure that the overall local financing budget is coherent.

\section{Foreign Aid and Local Financing.}

18. The main issue here is aid fungibility in the context of local financing, that is, whether or not aid fungibility would help to mitigate the local financing gap. To emphasize, the issue is not the on-going debate in the development community about whether or not aid is fungible, and what the implications of such fungibility may be for project financing. In the context of a local financing gap, even if project aid is shown to be fungible, there is still an issue as to whether or not such fungibility translates into resource flows to redress the local financing gap. Various scenarios of aid fungibility may be envisaged. First, perfect aid fungibility would mean (i) that aid replaces activities the government would have financed with own resources anyway, and (ii) that government has flexibility to convert project aid to non-project aid, depending on the

\footnotetext{
${ }^{3}$ For illustration purposes only, the seigniorage rate is defined simply as the product of GDP growth (4.5), the elasticity of money demand (1.5), and currency to GDP ratio (6.5). Local currency obtained equals the seigniorage rate multiplied by total GDP of US\$ 7 billion. Based on the currency to GDP ratio of 6.5 , total currency is US\$ 455 million. Therefore, the local funds of US\$ 31 million obtained from seigniorage is equivalent to 7 percent growth in currency. Seigniorage will be lower if the substitution effects of money demand relative to inflation, interest rates and exchange rates are considered. See Adams, et al. 1996.
} 
perceived budgetary resource constraint. Under these conditions, the local financing gap would not be distinguished from the foreign financing gap; the concern would be with the total resource gap. In reality, LDCs often have project aid which they are not able to absorb because of inadequate complementary local resources.

19. Second, aid fungibility may be reflected in a shift of resources to increase the holding of external assets or meet debt service obligations. In this case, the impact of fungibility would not be reflected on development spending. Third, even if project aid is fungible among sectors, such project aid may, nevertheless, widen the local financing gap in the short to medium term because of the related matching funds as well as recurrent cost financing requirements. This would be more so for countries which do not generate own resources to finance development expenditures, and would not have any sustained public investments without aid. However, in the longer term, aid may help to narrow the local financing gap through its impact on growth and on the tax revenue base.

20. The empirical evidence indicates some aid fungibility, but this is complex. $H$. Park and J. R. Park $(1990,1992)$ found positive impact of aid on local fund mobilization in Indonesia, but not in the Dominican Republic. In the latter, aid fungibility was reflected in reduced revenues and shifts from development expenditures to deficit reduction and debt service. In the former, there was virtually no indication of aid fungibility. Aid stimulated both revenues and total expenditures. There was no indication of resource diversion from sectors such as industry, tourism, mining, electricity and transport. Moreover, aid fostered local resource flows to sectors, such as agriculture, education, health, water supply and housing. These results reflected Indonesia's strong growth and enhanced revenue capacity, and the emphasis on limiting aid dependence.

21. In other cases, Victor Levy (1988) and Peter Boone $(1994,1996)$ found that aid fungibility promoted consumption rather than investment and growth in the developing countries. An exception is in a few low income countries where average annual aid is generally more than 15 percent of GDP. Fungibility was found to be less in low income countries where much of the aid is project finance. The overall impact of aid on investment finance and growth was found to depend on the commitment of the political elite to development. Some of these results obtained by Levy and Boone suffer from inadequate distinction between public consumption and recurrent expenditures. For example, expenditures on education and health, which are mostly recurrent, are typically classified as consumption, though they enhance the quality of human capital and are as critical for growth as physical capital. More recently, Swaroop and Zhu (1996) found from a sample of developing countries that concessional aid for education was partially fungible, while concessional aid for transport and communication was not. ${ }^{4}$

22. Overall, the empirical literature confirms aid fungibility generally; however, this does not necessarily translate into resource flows to enhance local financing. The

${ }^{4}$ For example, a dollar of concessional aid to agriculture, education and energy was found to have resulted in increase of US\$ 0.11 , US\$ 0.49 , and US\$ 0.36 for each of the sectors. 
importance of fungibility for local financing varies by sector; it depends on the size of aid relative to the economy and on the attitude of the ruling elite towards economic growth and development (Schmidt-Hebbel et al., 1996). Aid fungibility may result in resource shifts away from sectors, such as education, which use local funds intensively. In the case of Indonesia, where there is no evidence of fungibility, there was strong emphasis on local resource mobilization to complement aid finance in the identified priority sectors. Reducing the local fund gap and raising aid productivity require government commitment to development, based on mobilizing internal resources to complement aid resources.

\section{Discussion and Analysis: Growth and Local Funds}

23. This section uses a simple macroeconomic framework (Appendix A) to examine the interaction among selected policies, local financing and economic growth. Figure 1, based on the framework, brings the discussion together in the context of two main variables, namely, national income $(\mathrm{Y})$ and the real exchange rate $(\mathrm{e})$, where $\mathrm{e}$ is the local currency value of foreign exchange in constant price terms. The framework comprises supply and demand functions for (i) output, (ii) local funds, (iii) foreign funds, and (iv) money. These relations are arranged to obtain equilibrium curves for output, local financing and foreign financing in the context of $\mathrm{Y}$ and $\mathrm{e}$ as shown in Figure 1.

24. The yy (or yoyo) curve in Figure 1, representing output demand and supply equilibrium, is upward sloping. Exchange rate reforms are expected to contribute to stimulating growth through, for example, (i) greater aid inflow to support investments and (ii) raising exports by correcting for price distortions, resource misallocation and under-employment that are normally inherent to over-valued exchange rate regimes. In this framework, only the nominal exchange rate, $\mathrm{E}$, is determined by policy directly. The real exchange rate, $\mathrm{e}$, is determined endogenously by price movements.

25. The $\mathrm{ff}$ (or fofo) curve in Figure 1 represents foreign financing demand and supply balance. As shown in Appendix A, ff may be upward or downward sloping, depending on the final outcome of the effects of output and real money growth on imports. If money demand growth raises import demand, then it will reinforce the impact of output growth on import demand. The overall effect would raise demand for foreign financing, and ff will be upward sloping. If, on the other hand, money demand growth results in lower demand for foreign currency, and if this dominates the effect of income growth on import demand, then real money demand growth from output growth will dampen demand for foreign financing, and e will have to decline to have foreign financing balance; the $\mathrm{ff}$ curve will be downward sloping and will be more elastic than the 11 curve. Figure 1 is based on the upward sloping ff case. The reader may analyze the other case.

26. The 11 (or lolo) curve in Figure 1 represents local fund supply and demand balances for various combinations of $\mathrm{Y}$ and $\mathrm{e}$. Output increase from expanding local financing through seigniorage or domestic credit would affect foreign reserves. A higher e will be required to ration the excess supply of local funds (excess demand for foreign 
Figure 1. Local and Foreign Financing Balances

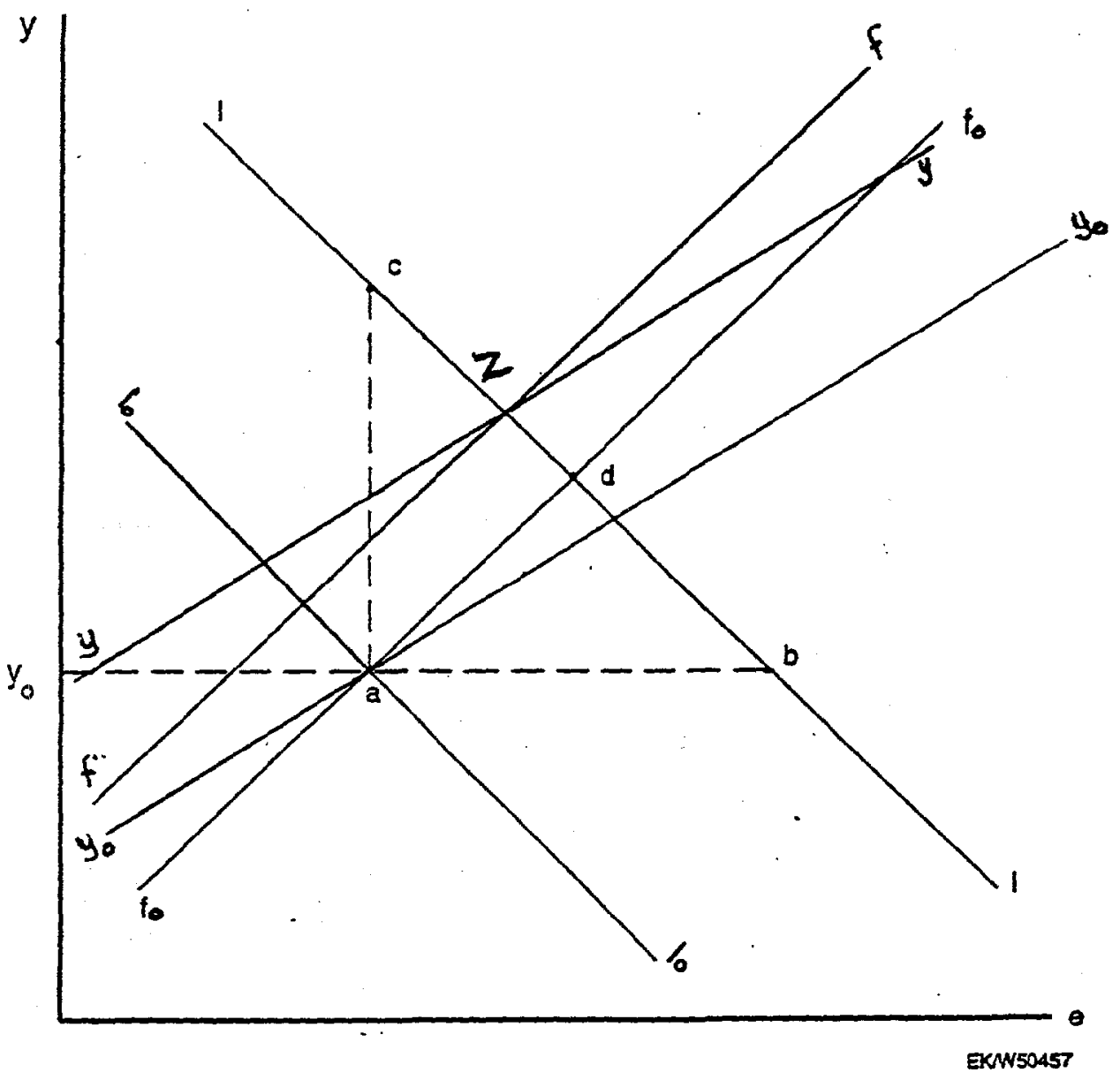


financing) by the government, and return to the 11 curve. A change in output would involve an inverse change of the real exchange rate to have local financing balance.

27. In Figure 1, from an initial equilibrium at "a," (lolo, yoyo, and fofo) suppose that government expands domestic credit to provide matching funds and implement aided projects, or to finance operation and maintenance and generate output from completed projects. The effect on output may be transmitted through investment in basic infrastructure, or improved human resource services and higher quality of the work force, which complements private investments. ${ }^{5}$ These activities could stimulate growth by raising productivity and making output supply price competitive. To illustrate with Figure 1, from "a", the initial effect of the expanded local expenditure is a shift in lolo to 11; this would harness available project aid resources. In addition, expanded domestic credit would spill-over onto demand for foreign goods and shift fofo to ff. Higher demand for output will cause output price to rise. The output price increases will have to be lower than the proportionate increase in the nominal exchange rate, leaving the final real exchange rate higher than initially. Output response to the competitive supply price and the higher real exchange rate will shift yoyo to yy to a new equilibrium at "z."

28. Economic growth is critical for the stability of the new equilibrium at "z." If there were no output response, then the increase in e induced by the increase in the nominal exchange rate, $\mathrm{E}$, will be eroded by price increases, and 11 will drift back to the initial output level yo corresponding to lolo. Another round of local fund increases will be needed to raise expenditure, leading to a new round of inflation and so on. The need for growth to have stability is independent of the method used to finance the expansion in local expenditures. If tax revenues were employed to support the increase in local expenditures, the tax increase will dampen private demand for imports and circumscribe the extent of real exchange rate adjustment. However, lack of growth response will mean periodic tax increases from the same tax base to sustain the higher local expenditures. Since the output stagnation implies that government expenditures are less efficient relative to the private sector, maintaining the expenditure at $l 1$ will create a heavy tax burden and frustrate growth even more. If the shift from lolo to ll were financed from local funds obtained from non-project aid, then without growth, maintaining 11 will require an open-ended commitment to providing the required non-project aid. This means more and more aid dependence to support local financing, and more debt burden.

29. Growth is critical to overcome the local financing gap in a sustained manner. The growth is essential to expand the base for local resource mobilization through tax revenues, seigniorage and domestic borrowing Underlying the growth emphasis is the presumption of an effective public investment screening process, so that development expenditures can generate high rates of return. In other words, fiscal adjustment programs have to protect the financing of high quality projects which can contribute to

\footnotetext{
${ }^{5}$ A most recent study (Deverajan, et al, 1996) provides a summary of the literature on government expenditures and growth, and presents new findings on channels through which sector recurrent expenditure shares (e.g., preventive health and subsidiary services to education) influence growth.
} 
growth. One cannot overstate the central importance of growth promotion and growthoriented policies for addressing local financing problems.

30. The conclusion about the importance of economic growth for mobilizing local funds from tax and seigniorage is equally relevant for domestic borrowing, though this is not modeled explicitly in the framework summarized in Appendix A. While a competitive banking system and sound macroeconomic and financial policies are key to using domestic borrowing to augment local funds, in the long term, a sustainable debt burden requires economic growth. To finance the public deficit in a sustained manner in the long run, the conventional wisdom is for demand for borrowing to maintain a constant ratio of debt stock to GDP at the existing real interest rates. Growth is essential for sustainable borrowing, given inflation, real interest rates, and ratio of debt to GDP.

\section{Country Illustrations}

31. Fiscal authorities in the LDCs, conversant with the impact of local fund shortages on development management, explicitly identify both the aid as well as the local financing requirements for implementing public investment programs. This is the case, for example, in Tanzania's Forward Rolling Budget Plan, and similarly for the public investment programs for Bangladesh and Nepal, to mention only a few. However, since countries facing a persistent local financing gap often have associated macroeconomic instability, stabilization policies (for example, to adjust government outlays, money growth, inflation and interest rates) often tend to heighten local fund shortages. For example, Sub-Saharan African countries experienced decline in local funds through reduced seigniorage between 1981-86 and 1990-91 with the spread in the adoption of stabilization programs. During these periods, average seigniorage rates in proportion to GDP fell from 1.6 to 1.3 percent for low income countries; 0.8 to 0.3 percent for middle income countries; and from one to zero percent for countries with fixed exchange rates. In Kenya, Ghana and Tanzania, the reduction in seigniorage was due mainly to reduced real money growth (Adams, et al, 1996). The initial phase of reforms was marked by reduced delivery of social services and inadequate maintenance of infrastructure assets.

32. Though there were no coherent programs focused on redressing local financing problems directly, country experiences show differences in the exact nature of the problem. In Kenya, for example, the tax to GDP ratio was already high at over 25 percent of GDP; thus key reforms focused on reducing the size of government, including the parastatal sector; limiting the excessive government wage bill and restructuring the financial sector to reduce high interest rate premium on government borrowing. In Tanzania and Ghana, on the other hand, tax reforms to mobilize more revenues were central to the fiscal adjustment effort. Other measures focused on rationalizing the civil service, streamlining development projects, and restructuring the financial institutions which were unable to mobilize and allocate financial savings effectively. In addition, access to non-project aid augmented the supply of local funds in all three countries.

33. Experience in South Asia varied. For example, Nepal in the early 1990s had the advantages of comfortable reserves, access to non-project aid and a transparent budgeting 
process, including reliable documentation of local fund sources and uses. In addition, management capacity in the Treasury was adequate. To protect the development budget while implementing fiscal reforms (including civil service and tax reforms) in the early 1990 s, Nepal adopted a program which had provisions for contingent domestic borrowing under specified conditions. The government could raise a specific amount of additional domestic credit beyond initial targets, if the tax revenue benchmark was being met; the external reserve position remained comfortable; and the additional local funds were required to support bigh quality development projects with good implementation performance acceptable to the Treasury. Subsequent political instability undermined efforts to maintain these sound and innovative fiscal practices.

\section{Conclusion}

34. Focusing on local financing gives new perspectives on the issues of aid, fiscal reform, and public expenditure management. First, fungibility would not necessarily translate into resource flows to fill the local financing gap. Project aid may widen the local financing gap because of the matching funds required to execute the investment, and the recurrent financing necessary to operate it on completion. For aid to augment local financing of development directly, it has to be a non-project aid that can generate local currency. In the longer term, the effect of project aid on local financing lies in its impact on growth and on expanding the base for tax revenues, seigniorage and borrowing.

35. Second, when local financing limits project aid absorption, it means that local currency resources are more valuable than project aid at the margin. The allocation of local funds becomes important for aid utilization and aid productivity. To improve overall efficiency in using public resources, including the allocation and utilization of local funds, project screening and public expenditure reviews need to pay as much attention to the quality of projects financed fully by local funds, as those funded by aid. Resource shifts from fully locally-funded projects to aided projects to enhance the overall quality of the public investment portfolio need to be given serious consideration. Where governments find review of own-funded projects intrusive, attention could be focused on strengthening local capacity in reviewing and managing the use of such local funds.

36. Third, a persistent local financing gap complicates fiscal reform programs. A fiscal program focused on matching aggregate expenditure plans against aggregate resources and glossing over the inner local financing gap tends to undercut the availability of matching funds for projects, thereby limiting the absorption of project aid and the implementation of the development budget. In the short term, the fiscal authorities may reduce capital formation and growth. In the medium term, they may succumb to political pressure and compromise prudent fiscal and financial goals. To have a realistic scope for sustained fiscal prudence, the local financing gap has to be confronted directly by matching planned local fund expenditures against expected local fund receipts. Effective management of local funds requires a transparent data base to develop indicators and to monitor the allocation and utilization of local fund resources. 


\section{APPENDIX A}

\section{Macroeconomic Framework}

$$
\begin{aligned}
& Y s=Y(e, g) \\
& Y d=C(Y-t Y, m(Y), e) \\
& L F s=L(Y, m(Y), e, t) \\
& L F d=B \\
& F F s=X(e) \\
& F F d=F(Y, m(Y), e) \\
& m d=m(Y) \\
& M=E R+D \\
& e=E / P \\
& g=P / W \\
& m=M / P
\end{aligned}
$$

1. Output supply $(\mathrm{Y})$ depends on foreign financing and local resources through the real exchange rate (e) and the supply price per unit of labor cost (g). Aggregate demand (Yd) depends on income net of taxes, real money balances and the real exchange rate. As discussed in the text, demand for local funds (LFd) depends on exogenous factors, especially population growth and pressure for social services. LFs, supply of local funds to the government, is influenced by the tax base $(\mathrm{Y})$, the tax rate $(\mathrm{t})$, money printing and the real exchange rate; net domestic borrowing is assumed to be nil. The supply of foreign financing (FFs) is influenced by exchange rate policy, and this determines both exports and aid inflows. Demand for foreign funds (FFd) is influenced by income, money balances and e. Money supply consists of reserves, ER, and domestic credit, D. E is the nominal exchange rate in units of local currency, and $R$ is reserves. Real money demand (md) depends on income. $\mathrm{P}$ is output price. $\mathrm{W}$ is the nominal wage rate.

2. The excess demand functions for output, local funds and foreign financing are represented by $\mathrm{H}$, I and $\mathrm{J}$ respectively in (12) to (14):

$$
\begin{aligned}
& \mathrm{H}=\mathrm{C}(\mathrm{Y}-\mathrm{t} Y, \mathrm{~m}(\mathrm{Y}), \mathrm{e})-\mathrm{Y}(\mathrm{e}, \mathrm{g}) \\
& \mathrm{I}=\mathrm{B}-\mathrm{L}(\mathrm{Y}(\mathrm{e}, \mathrm{g}), \mathrm{m}(\mathrm{Y}), \mathrm{t}) \\
& \mathrm{J}=\mathrm{F}(\mathrm{Y}, \mathrm{m}(\mathrm{Y}), \mathrm{e})-\mathrm{X}(\mathrm{e})
\end{aligned}
$$

3. Differentiating (12) to (14) totally and imposing equilibrium conditions lead to the equations (15) to (17). Ye is the partial derivative of $Y$ with respect to the real exchange rate; $\mathrm{Fm}$ is the partial derivative of foreign financing with respect to money balances, and similarly for $\mathrm{Yg}, \mathrm{Xe}, \mathrm{Ce}, \mathrm{Cm}, \mathrm{Ct}, \mathrm{Cy}, \mathrm{my}, \mathrm{Lt}, \mathrm{Le}, \mathrm{Lm}, \mathrm{Ly}, \mathrm{Fe}, \mathrm{Ct}$ and $\mathrm{Fy}$.

Output: $\mathrm{dY} / \mathrm{de}=(\mathrm{Ye}+(\mathrm{Yg}) \mathrm{dg} / \mathrm{de}+\mathrm{Y}(\mathrm{Ct}) \mathrm{dt} / \mathrm{de}-\mathrm{Ce}) /((\mathrm{Cm}) \mathrm{my}+\mathrm{Cy}(1-\mathrm{t}))$ 


$$
\begin{aligned}
& \text { Local Funds: } d Y / d e=(d B / d e-L e-(L t) d t / d e) /(L y+(L m) m y) \\
& \text { Foreign Funds: } d Y / d e=(X e-F e) /(F y+(F m) m y)
\end{aligned}
$$

4. For output equilibrium in (15), dY/de $>0$, meaning yoyo and yy curves in Figure 1 will be upward sloping. In (15) $\mathrm{Ye}>0$ because devaluation is expected to generate positive output response through correcting for price distortions, resource misallocation and under-employment, and the relatively low labor intensity of production, that is inherent in an over-valued exchange rate. $\mathrm{Yg}>0$, indicating a positive supply price response; $\mathrm{dg} / \mathrm{de}>0$, since increasing $\mathrm{E}$ must cause $\mathrm{P}$ to rise but less than proportionately so that $\mathrm{e}$ would be higher than before the exchange rate adjustment. Output demand responds negatively to e and positively to $\mathrm{m}$ and $\mathrm{Y}$; thus, we have $\mathrm{Ce}<0 ; \mathrm{Cm}>0 ; \mathrm{Cy}>0$.

5. For local funds equilibrium in (16), dY/de $<0$; that is, 11 or lolo in Figure 1 will be downward sloping. $d B / d e=0$, since $B$ is exogenous, but $d B / d e<0$ could be due to increases in e leading $P$ to rise and causing $B$ to fall in real terms. $L y>0$; Le $>0$; my $>0$, as real income growth expands the base increasing the supply of local funds through the positive effect of devaluation on income and, therefore, tax revenues and seigniorage. Increases in the tax rate and money balances impact positively on the supply of local funds, that is, $\mathrm{Lt}>0, \mathrm{Lm}>0$; but $\mathrm{dt} / \mathrm{de}=0$, the tax rate is independent of $\mathrm{e}$.

6. For foreign financing equilibrium in (17), dY/de may be positive or negative. Exchange rate depreciation will dampen demand for foreign financing, so that $\mathrm{Fe}<0$; and it will raise the supply of foreign funds, that is, $\mathrm{Xe}>0$. Increases in income will raise money demand (my $>0)$ and higher money growth may raise demand for imports and for foreign financing ( $\mathrm{Fm}>0)$; thus dY/de $>0$ in (17), meaning ff in Figure 1 will be upward sloping. On the other hand, increases in real money balances from output growth may dampen demand for foreign exchange; that is, Fm $<0$, making the sign of (Fy + Fm.my) in (17) ambiguous. If Fy dominates (Fm)my, then $\mathrm{dY} / \mathrm{de}>0$ as noted earlier. However, if $(\mathrm{Fm})$ my dominates $\mathrm{Fy}$, then $\mathrm{dY} / \mathrm{de}<0$. Reduced local fund expenditures would lower output and money demand, putting pressure on demand for foreign currency, and this will overwhelm the effect of the decline in output on imports and related foreign exchange demand; the real exchange rate will have to rise to restore foreign financing balance. The equilibrium curve of FF (ff or fofo in Figure 1) will be downward sloping, and will be more elastic than that of the LF curve (1l or lolo) in Figure 1. 


\section{References}

Agbonyitor, Albert. 1985. "Recurrent Expenditure Commitment, External Imbalance, Inflation and Devaluation in the Developing Countries." Journal of Economic Development Vol. 10 No. 2: 87-99.

Adams, Christopher, Benno Ndulu, and Nii Kwaku Sowa. 1996. "Liberalization and Seigniorage Revenue in Kenya, Ghana and Tanzania." Journal of Development Studies. 32, 4 (April): 531-53.

Baumol, William. 1967. "Macroeconomics of Unbalanced Growth. The Anatomy of Urban Crisis." American Economic Review. No 57 (June): 415-26.

Beck, Morris. 1982. "Towards a Theory of the Public Sector Growth." Public Finance. 163-76.

Boone, Peter. 1994. The Impact of Aid on Savings and Growth. London School of Economics. Mimeo.

-1996. "Politics and the Effectiveness of Foreign Aid." European Economic Review No 40: 289-329.

Bruton, Henry. 1969. "The Two-Gap Approach to Aid and Development: Comment." American Economic Review 59 (June): 439-46.

Burnside, Craig and David Dollar. 1997. Aid, Policies and Growth. Policy Research Working Paper No. 1777 (June) World Bank. Washington D. C.

Chennery, Hollis, and Allen M. Strout. 1966. "Foreign Assistance and Economic Development." American Economic Review. Vol. 56, No. 4 (September ): 679-733.

Christ, Carl. 1979. "On Fiscal and Monetary Policies and the Government Budget Restraint." American Economic Review. No 69 (December): 526-38.

Club du Sahel. 1980. Working Group Report on Recurrent Costs of the Developing Countries of the Sahel, Analysis and Recommendations. Harvard Institute for International Development (August).

Deverajan, Shantayanan, Swaroop Vinaya, and Zou, Heng-fu. 1996. "The Composition of Public Expenditure and Economic Growth." Journal of Monetary Economics 37: 313-344

Dorrace, Graeme S. 1965. "The Instruments of Monetary Policy in Countries Without Highly Developed Capital Markets." IMF Staff Papers No (12): 272-79.

Easterly, William, Paolo Maoro, and Klaus Schmidt-Hebbel. 1995. "Money Demand and Seigniorage-Maximizing Inflation." Journal of Money Credit and Banking (May): 583-603

Easterly, William. 1997. The Ghost of the Financing Gap: How the Harrod-Domar Growth Model Still Haunts Development Economics (May). World Bank Mimeo. 
Fei, John, and Gustav Ranis. 1968. "Foreign Assistance and Economic Development: Comment." American Economic Review 58 (September): 897-912.

Fischer, Stanley and William Easterly. 1990. "The Economics of the Government Budget Constraint." The World Bank Research Observer Vol. 5, No 2 (July): 127-42.

Gandhi, Ved. 1970. Levels and Structure of Public Expenditure in Africa. World Bank Working Paper. No 69 (December).

Heller, Peter. 1974. "Public Investments in LDCs with Recurrent Cost Constraint: The Kenya Case." Quarterly Journal of Economics Vol. 88, (May): 250-77.

------1975. "A model of Fiscal Behavior in the Developing Countries." American Economic Review' 429-45. 1979. "The Under-financing of Recurrent Development Costs." Finance and Development Vol. 16, (March): 38-41.

Jennings, A. 1983. "The Recurrent Cost Problem." Journal of Development Studies. 505-21.

Khalilzadeh-Shirazi, Javad, and Anwar Shah. 1991. Tax Policy in Developing Countries. World Bank: Washington D.C.

Killick, Tony. 1978. Economic Development in Action. New York: St. Martin's Press.

Kumar, P.C. 1994. Internal Sources of Development Finance: Concepts, Issues and Strategies. London: Quorum Books.

Kuznetz, Simon. 1966. Modern Economic Growth, Rate Structure and Spread. New Haven: Yale University Press.

Lau, S. 1969. "A Note on Government Expenditure in he Developing Countries" Economic Journal 74 (June): 413-17

Lele, Uma. 1975. Lessons from Rural Development in Africa. Baltimore: John Hopkins University Press.

1979. "A Revisit to Rural Development in Eastern Africa." Finance and Development. 31-35.

Levy, Victor. 1987 "Anticipated Development Assistance, Temporary Relief Aid, and Consumption Behavior of Low-income Countries." The Economic Journal 97: (June): 446-58.

Martin, Allison, and Arthur Lewis. 1956. "Patterns of Public Revenue and Expenditure." Manchester School (24): 203-44.

Musgrave, Richard. 1969. Fiscal Systems. New Haven: Yale University Press.

Mwega, F. M., Njuguna Mwangi, and F. Olewe-Ochilo. 1994. "Macroeconomic Constraints and Medium Term Growth in Kenya: A Three-Gap Model." African Economic Research Consortium. Nairobi. 
Ndulu, Benno. 1990. "Growth and Adjustment in Sub-Saharan Africa." African Economic Research Consortium. Nairobi.

Over, Mead Jr. 1981. On the Care and Feeding of a Gift Horse: The Recurrent Cost Problem and Optimal Reduction of Recurrent Inputs. William's College: Center for Development Studies.

Pack, Howard, and Janet R. Pack. 1990. "Is Foreign Aid Fungible? The Case of Indonesia." The Economic Journal 100 (March): 188-94.

-193. "Foreign Aid and the Question of Fungibility." Review of Economics and Statistics Vol. 75 No 2 (May): 258-65.

Peacock, Alan, and Jack Wiseman. 1967. The Growth of Public Expenditure in the United Kingdom. London: George Allen and Urwin.

Pluta, Joseph. 1981. " Real Public Expenditure Growth and Decline in the Developing Countries." Public Finance 429-51.

Ricardo, David. 1943. Principles of Political Economy. New York: E. P. Dutton and Co Inc.

Schmidt-Hebel, Klaus, Luis Serven, and Andres Solimano. 1996. "Savings and Investment: Paradigms Puzzles, Policies". The World Bank Observer. Vol. 11 No 1 (February): 87-117.

Stiglitz, Joseph E. 1996. "The Role of Government in Economic Development" in Annual World Bank Conference on Development Economics 9-23

Swaroop, T. N., and M. Zhu. 1996. Foreign Aid Impact on Public Spending. World Bank, Policy Research Working Paper No 1610.

Taylor, Lance. 1993. "The Rocky Road to Reform: Trade, Industrial, Financial and Agricultural Strategies." World Development Vol. 21, No. 4: 577-590.

Wagner, Adolph. 1883. "Three Tracts on Public Finance" 3rd edition, Leipzig, in Richard Musgrave and Alan Peacock (eds.) Classics in the Theory of Public Finance. New York: Macmillan (1958): 1-15.

World Bank. 1992. Annual Review of Evaluation Results, 1991.

World Bank. 1994a. Annual Review of Evaluation Results, 1993.

World Bank. 1994b. Adjustment in Africa. Oxford University Press.

World Bank. 1995. Annual Review of Evaluation Results, 1994. 


\section{Policy Research Working Paper Series}

Title

WPS1883 Intersectoral Resource Allocation and Fumihide Takeuchi its Impact on Economic Development Takehiko Hagino in the Philippines

WPS1884 Fiscal Aspects of Evolving Federations: Issues for Policy and Research

WPS1885 Aid, Taxation, and Development: Analytical Perspectives on Aid Effectiveness in Sub-Saharan Africa

WPS1886 Country Funds and Asymmetric Information

WPS1887 The Structure of Derivatives Exchanges: Lessons from Deveioped Panos Varangis and Emerging Markets

WPS1888 What Do Doctors Want? Developing Incentives for Doctors to Serve in Indonesia's Rural and Remote Areas

WPS1889 Development Strategy Reconsidered: Toru Yanagihara Mexico, 1960-94

WPS1890 Market Development in the United Kingdom's Natural Gas Industry

WPS1891 The Housing Market in the Russian Federation: Privatization and Its Implications for Market Development

WPS1892 The Role of Non-Bank Financial Intermediaries (with Particular Reference to Egypt)

WPS1893 Regulatory Controversies of Private Pension Funds

WPS1894 Applying a Simple Measure of Good Governance to the Debate on Fiscal Decentralization

WPS1895 The Emergence of Markets in the Natural Gas Industry

WPS1896 Congestion Pricing and Network Expansion
Jeffrey A. Frankel Sergio L. Schmukler George Tsetsekos Gunawan Setiadi

Azrul Azwar

Nusye !smail

Widiyarti

Yoshiaki Hisamatsu

Andrej Juris

February 1998

Alla K. Guzanova

Dimitri Vittas

Dimitri Vittas

Jeff Huther

Andrej Juris

Thomas-Olivier Nasser

\section{Date}

February 1998

February 1998

February 1998

March 1998

March 1998

March 1998

March 1998

March 1998

March 1998

Contact

for paper

K. Labrie 31001

C. Bernardo 31148

K. Labrie 3†001

R. Martin 39065

P. Kokila 33716

T. Charvet 87431

K. Labrie 31001

S. Vivas 82809

S. Graig 33160

P. Sintim-Aboagye 38526

March 1998

P. Sintim-Aboagye 38526

March $1998 \quad$ S. Valle 84493

S. Vivas 82809

March 1998 


\section{Policy Research Working Paper Series}

Title

WPS1897 Development of Natural Gas and Pipeline Capacity Markets in the United States

WPS1898 Does Membership in a Regional Preferential Trade Arrangement Make a Country More or Less Protectionist?

WPS1899 Determinants of Emerging Market Bond Spread: Do Economic Fundamentals Matter?

WPS1900 Determinants of Commercial Bank interest Margins and Profitability: Some International Evidence

WPS1901 Reaching Poor Areas in a Federal System

WPS1902 When Economic Reform is Faster than Statistical Reform: Measuring and Explaining Inequality in Rural China

WPS1903 Taxing Capital Income in Hungary and the European Union

WPS1904 Ecuador's Rural Nonfarm Sector as a Route Out of Poverty

WPS1905 Child Labor in Côte d'Ivoire: incidence and Determinants

WPS1906 Developing Countries' Participation in the World Trade Organization
Author

Date

Andrej Juris

March 1998

Faezeh Foroutan

March 1998

Niarch 1998

Hong G. Min

Asli Demirgüç-Kunt Harry Huizinga

Martin Ravallion

Martin Ravallion

Shaohua Chen

Jean-Jacques Dethier

Christoph John

March 1998

Peter Lanjouw

March 1998

Christiaan Grootaert

March 1998

Constantine Michalopoulos March 1998
Contact

for paper

S. Vivas

82809

L. Tabada

36896

E. Oh

33410

P. Sintim-Aboagye 37656

P. Sader

33902

P. Sader 33902

J. Smith

87215

P. Lanjouw

34529

G. Ochieng 31123

L. Tabada 36896 